\title{
Comparing the catch composition, profitability and discard survival from different trammel net designs targeting common spiny lobster (Palinurus elephas) in a Mediterranean fishery
}

Gaetano Catanese ${ }^{\text {Corresp., }}$ 1, 2, Hilmar Hinz ${ }^{3}$, Maria del Mar Gil ${ }^{1,3}$, Miquel Palmer ${ }^{3}$, Michael Breen ${ }^{4}$, Antoni Mira ${ }^{5}$, Elena Pastor ${ }^{1}$, Amalia Grau ${ }^{1}$, Andrea Campos-Candela ${ }^{3}$, Elka Koleva ${ }^{3}$, Antoni Maria Grau ${ }^{5}$, Beatriz Morales-Nin ${ }^{3}$

${ }^{1}$ Laboratori d'Investigacions Marines i Aqüicultura (LIMIA), Govern de les Illes Balears, Port d'Andratx, SPAIN

2 Instituto de Investigaciones Agroambientales y de Economía del Agua (INAGEA), Palma de Mallorca, SPAIN

3 Instituto Mediterraneo de Estudios Avanzados (IMEDEA; CSIC-UIB), Esporles, Illes Balears, SPAIN

4 Institute of Marine Research (IMR), Bergen, NORWAY

5 Direcció General de Pesca i Medi Marí, Govern de les Illes Balears, Palma de Mallorca, SPAIN

Corresponding Author: Gaetano Catanese

Email address: gcatanese@dgpesca.caib.es

In the Balearic Islands, different trammel net designs have been adopted to promote fisheries sustainability and reduce discards. Here, we compare the catch performance of three trammel net designs targeting the spiny lobster Palinurus elephas in terms of the biomass amount, species composition and revenue from commercial catches and discards. Designs differ in the netting fiber type (standard polyfilament, PMF, or a new polyethylene multi-monofilament, MMF) and the use of greca, a mesh piece intended to reduce discards. Catches were surveyed by an on-board observer from 1,550 netting walls corresponding to 70 nets. The number of marketable species captured indicated that the lobster trammel net fishery has multiple targets, which contribute significantly to the total revenue. The discarded species ranged from habitat-forming species to elasmobranches, but it remains unclear whether lobster trammel nets interact with benthos dynamics. No relevant differences in revenue and weight of discards were detected after Bayesian analyses. However, the species composition of discards was different when using greca. Interestingly, high immediate survival was found for discarded undersized lobsters, while a seven days survival assessment, using captive observation, gave an asymptotic estimate of survival probability of 0.64 ( $95 \%$ confidence interval: 0.54 to 0.76 ). Therefore, it is recommended that it would be beneficial for this stock if an exemption from the EU landing obligation regulation was sought for undersized lobsters in the Balearic Trammel Net fishery. 
1 Comparing the catch composition, profitability and discard survival from

2 different trammel net designs targeting common spiny lobster (Palinurus

elephas) in a Mediterranean fishery

5 GAETANO CATANESE ${ }^{1,2}$, HILMAR HINZ ${ }^{3}$, MARIA DEL MAR GIL ${ }^{1,3}$, MIQUEL PALMER $^{3}$, 6 MICHAEL BREEN ${ }^{4}$, ANTONI MIRA ${ }^{5}$, ELENA PASTOR ${ }^{1}$, AMALIA GRAU ${ }^{1,2}$, ANDREA 7 CAMPOS-CANDELA ${ }^{3}$, ELKA KOLEVA ${ }^{3}$, ANTONI MARIA GRAU $^{5}$, BEATRIZ MORALES$8 \quad \mathrm{NIN}^{3}$

1 Laboratori d'Investigacions Marines i Aqüicultura (LIMIA) - Govern de les Illes Balears, Av.

11 Enginyer Gabriel Roca 69, 07158 Port d'Andratx - Illes Balears (Spain)

122 INAGEA (INIA-CAIB-UIB) - Carr. de Valldemossa, km 7,5, 07122 Palma, Illes Balears (Spain)

133 Instituto Mediterraneo de Estudios Avanzados (IMEDEA; CSIC-UIB), C/ Miquel Marquès 21,

14 E-07190 Esporles, Illes Balears

154 Institute of Marine Research (IMR), C. Sundts gate 64, 7th floor, NO-5817 Bergen

16 (Norway)

175 Direcció General de Pesca i Medi Marí. Govern de les Illes Balears, C/ Foners 10, 07006 Palma, 18 Illes Balears (Spain)

21 Correspondence: G. Catanese LIMIA - Govern de les Illes Balears, Av. Gabriel Roca 69, 07158

22 Port d'Andratx - Mallorca, Spain

23 Email: gcatanese@dgpesca.caib.es 


\section{ABSTRACT}

In the Balearic Islands, different trammel net designs have been adopted to promote

26 fisheries sustainability and reduce discards. Here, we compare the catch performance of three

27 trammel net designs targeting the spiny lobster Palinurus elephas in terms of the biomass amount,

28 species composition and revenue from commercial catches and discards. Designs differ in the

29 netting fiber type (standard polyfilament, PMF, or a new polyethylene multi-monofilament, MMF)

30 and the use of greca, a mesh piece intended to reduce discards. Catches were surveyed by an on-

31 board observer from 1,550 netting walls corresponding to 70 nets. The number of marketable

32 species captured indicated that the lobster trammel net fishery has multiple targets, which

33 contribute significantly to the total revenue. The discarded species ranged from habitat-forming

34 species to elasmobranches, but it remains unclear whether lobster trammel nets interact with

35 benthos dynamics. No relevant differences in revenue and weight of discards were detected after

36 Bayesian analyses. However, the species composition of discards was different when using greca.

37 Interestingly, high immediate survival was found for discarded undersized lobsters, while a seven

38 days survival assessment, using captive observation, gave an asymptotic estimate of survival

39 probability of 0.64 (95\% confidence interval: 0.54 to 0.76$)$. Therefore, it is recommended that it

40 would be beneficial for this stock if an exemption from the EU landing obligation regulation was

41 sought for undersized lobsters in the Balearic Trammel Net fishery.

42

43 


\section{INTRODUCTION}

45

The discarding of the unwanted or non-marketable fraction of catch, has globally been recognised as one of the most pressing issues for fisheries management (Hall \& Mainprize, 2005). Discarding is seen as a wasteful non-usage of marine natural resources that can negatively affect the sustainable exploitation of marine biological resources and marine ecosystems, as well as the long term financial viability of fisheries (Kelleher, 2005). For this reason, the EU Common Fisheries Policy (CFP) introduced the Landing Obligation (LO) for such discards (Regulation EC 1380/2013). For Mediterranean fisheries, the new regulation mainly affects the discarding of juveniles of species for which a minimum landing size is mandatory. The goal of the regulation is to provide incentives for more selective fishing and to provide reliable data to facilitate better recording control over actual catches.

Not all fisheries are equally affected by the European landing obligation. In this context, objective knowledge of discard composition related to specific fisheries is needed to provide evidence for scientific advice to implement adequate management policies and mitigation methods if required. Data on the discard amount and composition are widely available for the large, closely managed, trawl fisheries in northern Europe and the Mediterranean, while for small-scale fisheries, particularly from the Mediterranean, such data are still sparse (Tsagarakis, Palialexis \& Vassilopoulou, 2014). However, in the Mediterranean, small-scale fisheries play an important socioeconomic role and have a long-lasting tradition (Morales-Nin, Grau \& Palmer, 2010; Stergiou et al., 2006). Small-scale fleets represent 80\% (42,000 boats) of the EU Mediterranean fishing vessels and contribute to $12 \%$ of the EU catches (Maynou et al., 2013; Morales-Nin, Grau \& Palmer, 2010). Current reported discard rates of trammel net fisheries in the Mediterranean vary between 10-43\% (Tsagarakis, Palialexis \& Vassilopoulou, 2014) depending on the species 
67 targeted. Discarding can be highly variable throughout time and depend not only on the catch 68 composition but also on market conditions, and legal restrictions (Batista, Célia \& Henrique, 69 2009; Veiga et al., 2006). While most of the existing studies report on the catch and bycatch of 70 vertebrate species few studies to date have include invertebrate or habitat forming organisms in 71 their assessment.

Most of the small-scale vessels in Majorca (Balearic Islands) use trammel nets of varying 73 designs to target both fish and shellfish (Quetglas et al., 2016; Palmer et al., 2017). The spiny lobster, P. elephas, is one of the economically most prized species affected by the LO in Balearic Islands and is listed in Annex III of the Regulation EC 1967/2006 (21 December 2006) as having a minimum size (see below). However, the LO regulations contrast substantially with the management rules currently applied by the local government, which requires releasing undersized juveniles and ovigerous (egg-bearing) female lobsters back to the sea. To-date, local management rules include: a) open fishing season limited to the time period between $1^{\text {st }}$ April and $31^{\text {st }}$ August 80 , to avoid the breeding period; b) a minimum landing size of $240 \mathrm{~mm}$ of total length (90 $\mathrm{mm}$ of carapace length, CL), which approximately coincides with the size at first maturity (Goñi \&

82 Latrouite, 2005); c) capture, retention on board and commercialization of ovigerous females is prohibited at any age and size; d) soaking time of the nets cannot exceed 48 hours to minimize 84 discard mortality; and e) the mesh size (full mesh knot to knot min. $133 \mathrm{~mm}$ ) and the total length of trammel nets (5,000 m) per vessel are also regulated (BOE 11324/2001; BOIB 38/2001). In general fishing boats in the Balearic Islands operate two trammel nets per fishing trip composed 87 of 25-28 panels with and approximate length of 100 meter to reach the allowed maximum length 88 (i.e. two $2.5 \mathrm{~km}$ nets). Fishers generally use mesh sizes considering full mesh knot to knot of 133 $89160 \mathrm{~mm}$. P. elephas is generally targeted at depth between 50 to 150 metres. In the Balearic Islands 
90 approximately 110 fishing vessels target spiny lobster at some moment of the year which

91 comprises about $42.6 \%$ of the total artisanal small scale fishery in the Balearic Islands (Data of

92 Balearic Government for 2017).

93

Fishing with trammel nets for spiny lobster has been one of the most important fishing

95

96

97 selvedge or guarding net, which is intended to reduce the discards from the sea bottom. While

111 monofilament netting are increasingly used the adoption of a guarding net has only been trialled

112 by fishers that participated in the present study. Therefore, one aim of the current study was to 
113 assess the effectiveness of these technological adaptations that fishermen are beginning to

114 implement in the Mediterranean to reduce discards, and to provide a detailed description of catches

115 and revenue from the wanted and unwanted fractions. Additionally, we investigate the immediate

116 survival of the most frequently discarded species, including undersized spiny lobsters.

117 Furthermore, we estimate the "short-term" (7-day) survival of undersized spiny lobsters by means

118 of observations in captivity.

119

120 MATERIALS AND METHODS

121 Sampling

122 A total of 35 fishing trips on three, small, commercial boats with lobster trammel nets were

123 surveyed in Majorcan waters off the Port d'Andratx and Portopetro harbors from April to August

124 in 2015 and 2016. Scientific sampling was carried out on fishing boats that conducted their normal

125 commercial activity while allowing for onboard observers under the condition of minimal

126 disruption to their activity. Sampling protocols were therefore adopted to maximising data

127 collection while mitigating disturbance of fishing procedures. Each boat was rigged with two sets

128 of trammel nets. A trammel net set consisted of several (between 10 and 30) netting walls (or

129 "netting panels"), each approximately $100 \mathrm{~m}$ long and with a mesh size of $160 \mathrm{~mm}$ (full mesh knot

130 to knot). Two manufacturing materials are currently used by fishermen in the Balearic Islands.

131 Netting walls studied were either composed of standard polyamide multifilament (PMF) or a new

132 polyethylene multi-monofilament (MMF). A total of 981 PMF and 499 MMF netting walls were

133 sampled. Trammel nets were either composed of one or a combination of the two materials.

134 Additionally, conventional MMF nets were compared to MMF nets with an additional

135 modification called greca (Fig. 1); which is considered to reduce the capture of unwanted benthic 
136 organisms and reduce negative impacts on demersal communities. A greca is a piece of net 137 approximately $20 \mathrm{~cm}$ high made of a thicker nylon material with a mesh size of $45 \mathrm{~mm}$ that is

138 sown to the bottom of the main net along its entire length. Trammel nets to test the effect of a 139 greca were composed of 10 netting walls alternating between $5 \mathrm{MMF}$ with a greca and $5 \mathrm{MMF}$

140 without a greca. Data from a total of 14 trammel net deployments were recorded. In total, 70

141 netting walls with greca and 70 without were evaluated. Apart from the netting materials and the

142 greca all trammel nets were comparable in their setup i.e. mesh size, net length, floats and lead

143 weighted rope used.

144 The date and time of deployment, location, soaking time, depth and type of net (PMF,

145 MMF or MMF with greca) were recorded by an observer on board. The organisms caught were

146 categorized into wanted ("marketable") and unwanted catches ("non-marketable") by the observer

147 following the decisions made by the fishermen about the catch. All the marketable species and

148 most of the large discarded species can be assigned to a specific netting wall because they remain

149 entangled in the net. Thus, the netting wall was considered as the sample unit for those animals,

150 which were immediately identified to the lowest taxonomic level possible, which was usually the

151 species level, and measured with a ruler or (if not possible) visually inspected and assigned into

152 10-cm length classes. Visual size assessments were done to allow rapid recordings of animals that

153 were manually removed from the net and directly discarded by the fishermen. 10-cm size bins

154 were chosen to facilitate length class allocation within a logistically difficult sampling

155 environment and to ensure consistencies between observers. Species were classified as belonging

156 to either the commercialized or non-commercialized fractions. It needs to be noted that during the

157 retrieval of the trammel nets part of the organisms that have been entangled in the net may become

158 dislodged during the process falling back into the sea before reaching the boat. As the dislodgment 
159 of entangled individuals can happen below as well as above the water this fraction cannot be

160 quantified during normal commercial activities. Quantifying this part of the catch would require

161 dedicated complex sampling involving scuba-divers and was outside the scope of the current study.

162 The abundances and biomass of catches presented are therefore relative values of the quantities

163 caught by the fishing gear used. These may underestimate the true absolute quantities of organisms

164 that did get entangled (caught) by the net. This data limitation is an inherent attribute of 165 commercial catch and bycatch studies. In addition, the survival status (i.e. alive or dead) was noted

166 for each discarded animal as the gear was hauled on board; where "dead" animals were observed

167 to have no reflexes or active movement following the protocol by Benoit, Hurlbut \& Chasse (2010)

168 described below in more detail.

169 During net retrieval, small invertebrates or bed-forming organisms (e.g. Posidonia 170 oceanica) were passively disentangling and falling on the deck in a continuous pattern; therefore,

171 it was not possible to assign this fraction of the catch to a specific netting wall. Instead, this fraction

172 was recorded at the level of the whole net and quantified by determining its total volume in litres.

173 A subsample of 20 litres in volume was taken and kept for further analysis at the laboratory from

174 which all items were identified to species level when possible and weighed. All data were 175 organized into a hierarchical (fishing trip, net, netting wall, and item) database.

176

177 Representativeness of the sampled boats

178 Due to logistical constrains, only three vessels were sampled. Therefore, to ensure the

179 representativeness of this sample, the commercialized catches of the three surveyed boats were 180 compared to catches made by the remaining fleet targeting lobster. Weight $(\mathrm{kg})$ and first sale price

181 (Euros $/ \mathrm{kg})$ for any sale of the entire Majorcan fleet are easily available because all sales of fish are 
182 carried out in the single fishing wharf of the island. The landings data can be disaggregated by

183 commercial category, day and boat and thus the commercialized catch is known for every fishing

184 trip (Palmer et al., 2017). Fishing trips with trammel nets targeting lobster were filtered out using

185 the algorithm described by Palmer et al. (2017). The data corresponding to 2015 and 2016 (the

186 same period as this study sampling) were used in a principal component analysis (PCA) using the

$187 r d a$ function of the vegan library (Oksanen et al., 2015) in the R package (R Development Core

188 Team 2008) on Hellinger-transformed data (Borcard, Gillet \& Legendre, 2011; decostand function

189 of vegan library). The similarity patterns in landings at the between-boat and within-boat level

190 were depicted and assessed using a plot of the scores in the first two dimensions of the PCA space.

192 After compiling all the fishing trips of the lobster trammel net fleet, the within-boat variability in 193 terms of landings composition (i.e., landed biomass of 170 commercial categories; Palmer et al.,

194 2017) was similar between the sampled boats and the rest of the fleet (Fig. 2). The convex hull 195 polygons that include all the fishing trips of the three sampled boats covered the same spatial area

196 in the graph as the average scores of the remaining boats in the fleet. The average scores of the 197 three commercial boats sampled were found well within the space occupied by the average scores 198 of the remaining fleet. This indicates that within-boat variability with respect to the season is 199 comparable or even greater than between-boat variability. Therefore, the three sampled boats could 200 be considered representative of the small-scale Majorcan lobster fishing fleet. 

sale in Euros) for any single individual were estimated from the weight and average price of the corresponding commercial category. Sale prices of a given category were estimated after averaging the sales prices of this category over all the trammel net fishing trips corresponding to the 2015 and 2016 spiny lobster fishing seasons.

After preliminary inspection of the cumulative (across species) revenue per netting wall, the observed distribution seemed to follow the same pattern as the biomass amount. Therefore, the same statistical model and Bayesian fitting approach described in the next section were adopted.

\section{Patterns of discards at the trammel and netting wall levels: effects of manufacturing material}

\section{and the use of greca.}

Between-species comparability in terms of abundance was problematic because discards ranged from large fish (e.g., rays) to fragments of reef-forming algae that cannot be enumerated as individual organisms. Due to the logistical constraint of sampling on-board of commercial vessels weight measurements could not be attained for fish thus total length measurements to the nearest $\mathrm{cm}$ were preferred for most individuals. To circumvent this problem, fish catches were converted to biomass (kg). Published length/weight relationships were used for this conversion (Morey et al., 2003; Ilkyaz et al., 2008; Bilge et al., 2014). However, when precise length measurements were not practical the organisms were assigned into 10-cm length classes (see justification above), except for Palinurus elephas which were assigned into 5-cm CL classes. For the calculation the maximum of each length class category was used. In the absence of a size record for an individual 225 item within a catch, the average size of the sampled conspecifics was used to estimate its weight.

226 Due to the low precision of visual length estimates and the absence of size data for occasional 
227 individuals as aforementioned the calculated biomass values need to be viewed with this limitation

228 in mind. For the invertebrate bycatch fraction weight was determined via a subsample in the

229 laboratory on land (see details above).

230 After preliminary inspection of the cumulative biomass (i.e., pooling weight across

231 species) per netting wall, the distribution of the data for netting walls in which some discard was

232 reported seemed to follow a negative exponential distribution, but the number of netting walls

233 without discards largely exceeded the expected value. Therefore, the following model was

234 considered:

235

236

237

238

where $x_{i}$ is the discarded biomass of the netting wall $i ; w_{i}$ is an indicator variable ( 0 in case of no

catch, 1 otherwise); mean $_{i}$ is the inverse of the characteristic parameter of the exponential

distribution for netting wall $i$, which results from combining mean.wall type $_{\text {, a fixed effect related to }}$

the type of manufacturing material (or the use of greca); and mean.rnd $d_{b o a t}$ and mean.rnd $d_{n e t}$ are random effects that accounted for the fact that all netting walls from a given boat or net were structurally linked. The strings dexp and dbinom indicate the assumed underlying distributions for

244 the exponential and binomial distributions, respectively. The parameters mean.rnd $d_{\text {boat }}$ and 245 mean.rnd $_{\text {net }}$ were assumed to be normally distributed with zero mean across boats or nets. Two 246 separate sets of analyses were completed: i) PFM versus MMF and ii) MMF versus MMF + greca.

247 The parameters of the model were fitted using a Bayesian approach. Samples from the joint 248 posterior distribution of parameters given the data were obtained using JAGS (Plummer, 2003;

249 http://mcmc-jags.sourceforge.net/). Virtually non-informative priors were set. A custom script 
250 calling JAGS via R2jags library from the R package ( $R$ Core Team, 2008) was used. Three Markov

251 chain Monte Carlo (MCMC) were run and 30,000 posterior samples were retained after proper

252 burning $(10,000)$ and thinning $(1 / 10)$. Convergence was assessed by visual inspection of the chains

253 and tested using the Gelman-Rubin statistic (Plummer et al., 2006). Thereafter, according to a

254 Bayesian framework, effects attributable to a given treatment were labelled statistically not

255 relevant or statistically relevant (corresponding to "statistically non-significant"/"statistically

256 significant" of classic inferential statistics) depending on whether their corresponding 95\%

257 Bayesian credibility intervals overlapped or not with a targed reference value.

258 In addition to the univariate analyses described above, differences in species composition

259 attributable to the manufacturing material or greca use were tested using a redundancy analysis

260 (RDA; Borcard, Gillet \& Legendre, 2011). The analyses were completed using the rda function

261 of the vegan library (Oksanen et al., 2015) in the R package on the Hellinger-transformed data

262 (Borcard, Gillet \& Legendre, 2011; decostand function of the vegan library). Between-category

263 differences were assessed using the permutation procedure implemented in the anova function

264 from the vegan library; thus, net level random effects were ignored.

265 Note that all the analyses above refer to the netting wall level, but some discards i.e.

266 invertebrate fraction could not be assigned to a given netting wall but only at the entire trammel

267 net level (see above). Thus, both fractions (i.e., items attributable to netting wall level and those

268 attributable to the net level) were pooled at the net level for a second set of analyses. After

269 preliminary inspection of the distribution of log-transformed cumulative (across species) biomass

$270(\mathrm{~kg})$ per trammel net, the data appeared to be normally distributed, which allowed a simpler

271 analysis in comparison with the analysis at the netting wall level. After removing all mixed nets

272 (i.e., those with netting walls composed of more than one fiber type), the differences attributable 
273 to fiber type in the log-transformed biomass were estimated using the function $l m$ in R. Note that

274 only MMF versus PMF was compared because the greca was always set in mixed nets.

275 In the analytical setup described above, using netting wall as a statistical unit, it can be deduced

276 that consecutive netting walls cannot be considered as statistically independent. To address this

277 concern the data were tested for the existence of spatial (i.e., between consecutive netting walls)

278 autocorrelation which was rejected justifying the use of the presented analyses at netting wall level

279 (For the test and its results see Fig. S1, Supplementary Information)

280

281 Survival assessment

282 Survival was assessed at two temporal scales: immediate and short-term (7 days). The aim

283 of the first method was to determine the immediate survival of the animals to be discarded when

284 the gear arrived on deck. The time that each animal had been retained in the net was unknown but

285 was less than the maximum soaking time (48 hours). The retrieval of the trammel net is relatively

286 quick, and the air exposure of the animals to be discarded during processing is usually less than 2

287 minutes. Animals to be discarded were identified and measured, and their survival status was

288 assessed. (see survival assessment method below) The following species were caught in sufficient

289 numbers ( $>30$ individuals) to permit a formal analysis: spiny lobster (P. elephas), cuckoo ray

290 (Leucoraja naevus), unidentified species of skates (Raja sp.), thornback ray (Raja clavata), lesser

291 spotted dogfish (Scyliorhinus canicula), red scorpionfish (Scorpaena scrofa), angler fish (Lophius

292 piscatorius) and royale cucumber (Parastichopus regalis). The proportion of living animals at

293 deck arrival was estimated from the ratio of living to total observed animals in the unwanted catch,

294 and the Bayesian 95\% credibility interval around that proportion was calculated using an ad hoc

295 R script (Table 1). 
297 discarded specimens of undersized lobsters collected in Port d'Andratx between 26/5/16 and 16/8/16 were transferred into small, aerated and refrigerated tanks and transported to an onshore laboratory (LIMIA facilities). The collection of juvenile lobster specimens for survival test was carried out under a specific permission of the Balearic Government. In the laboratory lobsters were placed in 5,000 L fiberglass tanks and supplied with a continuous flow of $100 \mu \mathrm{m}$ filtered and refrigerated water; the temperature was maintained below $18^{\circ} \mathrm{C}$. The tank was also equipped with plastic tub shelters. Tanks had a maximum occupancy of 5 individuals, to avoid stress and aggressive behaviour among individuals. The individuals were fed once per day with fish. The \& Chasse, 2010; Table S1, Supplemental Information) which is based on an evaluation of damage and reflex impairment closely related to the reflex action mortality predictor (RAMP) proposed by Davis \& Ottmar (2006): on days zero, one, two, four and seven. At the end of the seven days observation period, all surviving individuals were then marked with ' $T$ ' marks and returned to the sea in a marine protected area. The small lobsters were submerged by scuba divers at a depth of

$31140 \mathrm{~m}$ and released at natural shelters to avoid predation. immediate and short-term survival data. For estimating survival probability and 95\% confidence

314 intervals, the surviving animals were assumed to be censored at day zero (i.e., when they came on

315 board). The analysis was conducted using the survival package (Therneau \& Grambsh, 2000) in $316 \mathrm{R}$.

\section{RESULTS}




\section{General catch patterns}

320 A total of 1,550 netting walls corresponding to 70 trammel nets and 35 fishing trips were

321 surveyed. The fishing depth ranged from 63 to $130 \mathrm{~m}$ (mean depth \pm S.D.: $94.4 \pm 19.3 \mathrm{~m}$ ). The

322 average soaking time was 45 hours. $(2.3 \pm$ S.D). The handling of the catch was generally fast, and

323 the disentangling of items from the net took 2 minutes maximum.

A total of 706 animals, from 19 species, comprised the wanted/marketable catch (Fig. 3A).

325

326

327

328

329

330

331

332

333

334

335

336

337

338

339

340

341

As expected, the most frequently recorded species was lobster, but other highly marketable species such as Scorpaena scrofa (17.68 Euros/kg) or Zeus faber (20.94 Euros/kg) were also frequently caught. Raja clavata was the third most common marketable species.

The average number of commercialized items per netting wall was low. The $95 \%$ quantiles of the number of animals per netting wall ranged from 0 to 3 with a median value of 0 . The biomass ( $\mathrm{kg}$ ) ranged from 0 to $4.4 \mathrm{~kg}$ with a median of 0 and a mean of $0.61 \mathrm{~kg}$ per netting wall. Finally, the $95 \%$ quantiles for revenues (Euros) ranged from 0.0 to 103.92 Euros with median of 0.0 and a mean value of 12.75 Euros per netting wall.

The total number of discarded species was 47 . The number of discarded animals recorded at the netting wall level was 1,465. The most frequent discards were elasmobranchs (Fig. 3A). Specifically, the three most frequently discarded species were rays (Rajidae). It is also noteworthy that the $5^{\text {th }}$ most commonly discarded species was the target lobster, where the discarded specimens were undersized. This species also was the main discard species with $6.35 \%$ following the EU landings obligation criteria. The "other" group included twenty-four different species, each one with less than 5 items per species. The number of discarded items per netting wall ranged from 0 to 4 (95\% quantiles), with a median of 1 . The biomass $(\mathrm{kg})$ per netting wall ranged from 0 to 4.6 $\mathrm{kg}$, with a median of $0.03 \mathrm{~kg}$ and a mean of $0.68 \mathrm{~kg}$ per netting wall. 
343 at the netting wall level with the fraction falling on deck) differed from that seen at the net panel

344 level (Fig. 3B). At the pooled net level, the most common species were the reef-forming,

345 calcareous algae of the genus Lithothamnion ssp. (maerl) followed by four elasmobranchs. The

346 overall discard faction by weight amounted to $69.74 \%$. Note, that the units in Fig. $3 \mathrm{~B}$ are $\mathrm{kg}$ and

347 not items in order to facilitate between species comparison i.e. inclusion of invertebrate and plant

348 fraction. Thus Lithothamnion spp. have a proportionally larger weight compared to other

349 organisms causing a bias in a direct comparison. Therefore, excluding maerl the discard faction by

350 weight was $52.71 \%$. Besides calcareous algae the discards also contained other habitat forming

351 organisms such as Seagrass (Posidonia oceanica), Ascidians (Botryllus schlosseri), Kelp

352 (Laminaria spp.), Sponges (Porifera) and hard corals (Dendrophyllia cornigera), indicating that

353 the fishing gear interacted with the benthos.

\section{Effects of manufacturing material and the use of greca on marketable catches}

Regarding the MMF vs PMF comparison (Fig. 4A), the proportions of netting walls/panels with some marketable catch were similar: $\mathrm{PMF}=0.31(95 \%$ Bayesian credibility, interval between 0.28 and 0.34$)$ versus $\mathrm{MMF}=0.28$ (95\% Bayesian credibility, interval between 0.24 and 0.32 ).

The estimated mean revenue when marketable items were reported in the netting wall was also similar: $\mathrm{PMF}=41.5$ Euros (32.9 to 50.3$)$ versus $\mathrm{MMF}=42.3$ Euros (31.5 to 52.6). The mean

361 revenue for an average net (22 netting walls), after combining the two different estimations to

362 calculate the expected mean commercialized catch per net, was PMF $=262.1$ Euros/net (63.5 to

363 504.2) and MMF = 242.5 Euros/net (44.9 to 563.8). In all three cases, the differences between

364 PMF and MMF were not considered statistically relevant. 
Concerning the standard MMF vs MMF + greca comparison (Fig. 4B), the differences in

366 the probability of obtaining some commercial catch were statistically not relevant: $\mathrm{MMF}=0.33$

$367(0.23$ to 0.44$)$ versus MMF + greca $=0.44(0.33$ to 0.56$)$. Similarly, the estimated mean revenue

368 when marketable items were reported in the netting wall did not to differ: MMF $=40.5$ Euros $(27.5$

369 to 62.5$)$ versus $\mathrm{MMF}+$ greca $=39.5$ Euros (27.9 to 57.7). After combining these estimates, the

370 differences in the expected (mean) revenues from the pooled net (22 netting walls) was -90.0

371 Euros/net favoured the MMF + greca, but this difference was not statistically relevant $(95 \%$

372 quantiles ranging between -540.9 to 331.7 Euros/net).

373

374 Effects of manufacturing material and the use of greca on non-marketable/discarded catch

375 Concerning the MMF vs PMF comparison at the netting panel level (Fig. 4C), the proportions of

376 panels with unwanted catch were similar: $\mathrm{PMF}=0.50(0.47$ and 0.51$)$ versus $\mathrm{MMF}=0.49(0.44$

377 and 0.53$)$. The estimated mean weight of discarded animals was also similar: PMF $=1.38 \mathrm{~kg}(0.70$

378 to 1.47$)$ versus $\mathrm{MMF}=1.34 \mathrm{~kg}(1.02$ to 1.71$)$. The differences in these two variables attributable

379 to net type were not relevant. The expected (mean) weight of discards at the net level (i.e. 22

380 netting walls pooled; the average number of netting walls per net) after combining the two model

381 parameters were $\mathrm{PMF}=14.0 \mathrm{~kg} /$ net (5.7 to 27.6) versus $\mathrm{MMF}=13.5 \mathrm{~kg} / \mathrm{net}$ (4.9 to 26.9). These

382 differences were not statistically relevant.

383 Comparing the standard MMF vs MMF + greca at the netting wall level showed relevant

384 differences in the probability of netting walls with unwanted catches (Fig. 4D): $\mathrm{MMF}=0.52(0.41$

385 to 0.63$)$ versus $\mathrm{MMF}+$ greca $=0.70(0.58$ to 0.79$)$. The estimated mean discarded weight was

386 statistically relevant, but in the opposite direction: $\mathrm{MMF}=1.30 \mathrm{~kg}$ (0.90 to 1.86) versus MMF +

387 greca $=0.62 \mathrm{~kg}(0.43$ to 0.91$)$. Thus, $\mathrm{MMF}+$ greca netting walls tended to retain some discarded 
388 fauna more frequently, but the overall mean weight of discards was smaller. At the net level, the

389 estimated amount of discard per net was smaller for MMF + greca, but the difference was not

390 statistically relevant (prob. $=0.20$; mean difference: $5.43 \mathrm{~kg}$; 95\% CI between 18.73 and $-5.6 \mathrm{~kg}$ ).

391 The RDA results for the differences in species composition are shown in Fig. 5. Differences

392 between net types were statistically significant (variance explained: 0.50 , residual variance $=$

$39321.49 ; \mathrm{F}=9.05 \mathrm{df}=2,767$; probability after 1,000 random permutations $<0.001)$. The main

394 differences in species composition between MMF/PMF versus $\mathrm{MMF}+$ greca was due to the 395 relative abundance of Scyliorhinus canicula (which has a smaller body size and was more 396 frequently caught with MMF + greca) (Fig. 6A) and Rajidae species (which have a larger body 397 size and were more frequently caught with MMF/PMF) (Fig. 6B).

398 The second set of analyses including all discards were pooled at the trammel net level, 399 standardized by the number of netting walls. In this case, the sample size considered (i.e., number 400 of nets) was smaller (44 nets) because nets with more than one type of manufacturing material 401 were removed, which is the case for all MMF + greca netting walls. The estimated mean biomass 402 of discards for PMF was $1.19 \mathrm{~kg} /$ netting wall (95\% confidence interval, 0.94 to 1.51$)$. The 403 corresponding figures for MMF were mean $=0.92 \mathrm{~kg} /$ netting wall $(0.63$ and 1.35$)$. In that case, 404 the differences between MMF and PMF in discards weight (kg) per trammel net, after accounting 405 for differences in the number of netting walls per net, were not significant (effect of the net type: $406 \mathrm{df}=1, \mathrm{SS}=0.57$; residual: $\mathrm{df}=41, \mathrm{SS}=17.67 ; \mathrm{F}=1.34, \mathrm{p}=0.25)$ (Fig.S2, Supplemental 407 Information).

408

409 Immediate and short-term survival assessment 
A total of 1,216 animals from eight species were examined at arrival on-board, and 353

411 were alive (Table 1). The immediate survival probabilities of the most abundant discarded species

412 (n > 30; P. elephas, L. naevus, and P. regalis) were all greater than 0.6. In contrast, the survival

413 probability of other commonly discarded species was less than 0.2 (Fig. 7).

A sample $(\mathrm{n}=16)$ of living, undersized spiny lobsters (mean $\mathrm{CL}=7.1 \pm 0.9 \mathrm{~cm})$ was kept

415 in captivity for 7 days. From that sample, only one lobster died that already had a 'poor' vitality

416 status on day zero. In contrast, the animals that were classified with a "good" vitality status on day

417 zero quickly improved vitality status to "excellent" (Fig. 8).

418 The data from immediate and short-term survival was combined using the Kaplan-Meier survival function (Fig S3, Supplemental Information). The survival curve reached an apparent asymptotic value after one day in captivity, which provided an asymptotic estimate of survival probability $(0.64 ; 95 \%$ confidence interval between 0.54 and 0.76$)$.

422

423 DISCUSSION

Within the present study we compared three trammel net designs (PMF, MMF and MMF

+ greca $)$ in terms of biomass, species composition and revenue of marketable catches and discards.

426 The statistical analyses suggested no differences between PMF and MMF in terms of probability of obtaining commercial catch or in cumulative (across-species) biomass/catch weights. The results for the non-marketable/unwanted fraction were statistically indistinguishable. Similarly, the comparison between MMF + greca and MMF showed no differences for the wanted and unwanted fractions. In summary, the new designs do not present an economic disadvantage nor a

431 relevant reduction of the cumulative discards across species. These results disagree with those

432 reported for the Mersin Bay small-scale fishery (Gökçe et al., 2016). In that case, using a greca-

433 like guarding net on the lead line of prawn trammel nets reduced the capture of discard species and 
434 the time required to clean the nets (Gökçe et al., 2016). Therefore, the usefulness of a given

435 technological novelty is probably case-specific.

436 The only reputed advantage of these nets, which has not been evaluated here, is the

437 potential reduction of expenses related with repair and maintenance. In this sense, damage

438 reduction has been reported when greca was used in red mullet (Mullus spp.) and shrimp

439 (Melicertus kerathurus) fisheries at the Aegean Sea (Metin et al., 2009; Aydin, Gökçe \& Metin,

440 2013). In these cases, the reduction of net damage was attributed to a reduced bottom contact of

441 the net with the seabed and the avoidance of capturing benthic invertebrates that appear to be

442 selectively excluded by the greca. Benthic invertebrates such as starfish, crabs or emergent fauna

443 can damage trammel nets by adding undesired weight to the bottom part, thus increasing seabed

444 contact and wear of the net. Furthermore, undesirable invertebrates once caught need to be

445 disentangled increasing the likelihood of wear and damage to the net during this process.

446 The results reported here for the greca indicate that it affects the capture of some non-

447 commercialized species. It reduces capture of rays but increases the capture of other smaller

448 elasmobranch species within our study. The processes leading to this pattern remain elusive, but

449 the phenomenon illustrates the need to more closely examine the operational mechanism of the

450 trammel net. In this type of net, the netting wall is formed by a main net characterized by a smaller

451 mesh size and a larger diameter thread at the centre with two further nets on either side, both with

452 wider meshes sizes and smaller thread diameter. When a fish tries to pass through this netting wall

453 it pulls at the central panel, which is slack, and when it tries to escape through the wider lateral

454 meshes, it becomes trapped. Because of the extra weight that the greca exerts on the netting wall,

455 the meshes may acquire rhombic forms, and reduce the level of slack in the panel effecting the

456 hanging ratio of the nets. Such circumstances could explain the differences in species composition 
457 mentioned above. Bigger and flatter fishes such as Raja spp. would have less chance to be trapped 458 due to the tension of the panel and to the deformation of the meshes. In contrast, smaller 459 elasmobranchs such as S. canicula, due to their fusiform morphology, would penetrate the exterior 460 panels and become trapped more easily in the more tensioned netting walls fitted with greca. The targeted spiny lobster species is generally caught by the trammel net when they are

462 attracted by the carcasses of previously trapped fish. This mechanism requires that the soaking 463 time of lobster trammel nets tends to be longer than for any other type of trammel net. This long 464 soaking time determines three relevant aspects in catch: i) the amount and composition of bycatch 465 and discards ii) the survival potential of caught species and iii) catch revenues. All three aspects 466 are discussed in the next paragraphs.

The first aspect is that the non-marketable fraction of catch from lobster trammel nets tends to be larger than in other small-scale fisheries in Mediterranean and Black Sea (Area FAO 37). which have been reported to discard between $5 \%$ to $43 \%$ of the catch (Tsagaraskis et al., 2011). If we consider only discards as species defined by the EU landings obligation, our results indicate a discard ratio of $6.35 \%$ (with discards being mainly comprised of undersized lobsters). This contrasts with $52.71 \%$ of discarded biomass if all organisms except maerl (Coralline algae) were included and $69.74 \%$ if maerl was included. Similar high discard ratios of over $40 \%$ for trammel net fisheries were reported for lobster fisheries by Quetglas et al. (2004) and for pawn fisheries by Gökçe and Metin (2007). Trammel net fisheries targeting mainly fish appear to have lower discard ratios. Stergiou et al. (2002) for example reported 5.1\% discards and Gonçalves et al. (2007) 14\%.

477 While the values reported by the present study appear significantly higher compared to other studies it needs to be considered that not all studies have included the invertebrate and plant

479 fraction in their discard calculations. Furthermore, various studies report the percentage of 
480 discarded items which will be distinct from the biomass values reported herein. Since no standard

481 reporting protocol exists not all reported discard percentages are strictly comparable.

482 Considering the \% discard levels reported for this study (see above) and the presence of

483 habitat forming organisms (e.g., maërl), the lobster trammel nets are clearly interacting with

484 benthic communities. While the experimental design implemented within this study does not allow

485 conclusions on the long-term effects of trammel nets on the benthos dynamics, they do provide

486 some indication of possible impacts. For example, maërl (calcareous red algae), which represented

487 the largest component by weight, while not negatively affected by fragmentation; i.e. maërl

488 propagation is facilitated by fragmentation (Irvine \& Chamberlain, 1994) it is not tolerant to

489 desiccation due to their low water content and lack of protective mucilage. As a consequence,

490 maërl show a significant decrease in survival when the thalli are out of the water for longer than 5

491 minutes (Wilson et al., 2004). This is a very likely time frame for unwanted catches to remain on

492 deck considering current fishing practices. This potential effect on maërl may be mitigated by

493 adapting fishing techniques to reduce capture and by returning maërl fragments caught in the net

494 immediately to the sea. While impacts of trammel nets on benthic habitats are thought to be

495 considerably lower than impacts from trawls fisheries, pots or traps are considered the least

496 damaging activity (Grieve, Brady \& Polet, 2014). Traditionally traps were the main fishing method

497 adopted in the Balearic Islands. However, the catch rates for traps in the Balearic Islands are lower

498 than for trammel nets (Amengual-Ramis et al., 2016) and thus traps have been discarded by the

499 fishing sector as being less economical and operational viable. Ultimately, the magnitude of

500 damage by trammel netting will depend on the intensity of fishing operations within an area and

501 its benthic community composition (Hinz, 2016). More research is needed to quantify the actual

502 disturbance caused by trammel nets on benthic habitats in the Balearic Island and elsewhere. To 
503 limit the effect of trammel netting on habitats operational mitigation measures should be

504 investigated in conjunction with the fishing sector.

505 The second aspect is related to the survival probability of the non-marketable fraction.

506 Some animals in the catch are alive when they arrive on board and may survive if returned to the

507 sea. The reasons for deciding that a given animal is not worth landing and can be returned to the

508 sea are diverse. For example, adherence to the local management rules demands that undersized

509 lobsters cannot be retained. The fraction of undersized lobsters ( $\mathrm{CL}<90 \mathrm{~mm}$ ) can be up to $80 \%$ in

510 Sardinia (Italy) (Secci et al., 1999); however, in the current study this fraction was 25.5\%, and a

511 similar figure (21.5\%) was reported by Quetglas et al. (2004). Considering the capture of

512 undersized lobsters one of the more relevant results reported here, although based on a relative

513 small number of samples, was the high survival probability of undersized $P$. elephas estimated at

5140.64 after combining immediate and short-term (7 days) survival in captivity. This result may be

515 indicative of the potential survival of undersized individual if returned to the sea. Further, other

516 non-marketable species were reported to have high survival ( $>60 \%)$ when they were brought on

517 deck: cuckoo ray (L. naevus) and the royale cucumber (P. regalis). P. elephas and P. regalis are

518 both invertebrates, which may make them more resilient to asphyxiation and attacks from

519 predators and scavengers. However, it is interesting that an elasmobranch species, L. naevus, also

520 demonstrated a high survival. In contrast, other non-commercial species showed low survival

521 capability. This is likely to be due to the prolonged soaking times of this fishery (up to 48 hours)

522 that can result in exhaustion, asphyxiation and injury of animals caught in the net, as well as by

523 predation from attracted predators and scavengers. As mentioned above, these prolonged soaking

524 times are a deliberate part of the fishing practice. Therefore, alternative gear configurations and/or

525 fishing tactics that reduce soaking time would be preferable and should be investigated. 
526 Furthermore, based on the results from the medium-term survival experiments of spiny lobsters, it

527 is recommended that further research should be conducted that may support a potential exemption

528 from the Landing Obligation of this species with respect to article 15 , paragraph $4 \mathrm{~b}$, of the

529 Common Fisheries Policy (EU Regulation 1380/2013). Returning ovigerous females and

530 undersized lobsters to the sea could provide substantial benefits to this exploited stock.

531 The third aspect related to the lobster trammel net fishing strategy concerns revenue. The

532 economic relevance of the trammel net fishery from Majorca not only relies on the target species

533 but also on several species of intermediate or high economic value, and this confirms that this and

534 other small-scale fisheries in the Mediterranean target multiple species. In this case, only $18 \%$ of

535 the catch corresponds to the target species and $14 \%$ to other marketable species. Therefore, fishers

536 appear to modulate their fishing tactics in response to the pooled revenue of their catch. Aiming to

537 explain fishers behaviour only considering the nominal target species may thus be naïve. For

538 example, a long net soaking time may increase lobster catches, but the marketable condition of

539 both lobster and other catch species is likely to improve by reducing the soaking time $(<48 \mathrm{~h})$.

540 Another trade-off may emerge between expected revenues and extra work that may change the

541 decisions of fishers on whether to land low-value species. In this case, the only species that was

542 frequently captured and occasionally marketed was thornback ray (Raja clavata). For this species,

543 the probability of discarding an individual significantly depends on size (the larger the fish, the

544 smaller the discarding probability; the size at which the discarding probability is $50 \%$ is $53.4 \mathrm{~cm}$ )

545 and on the number captured during a given fishing trip (more fish captured means smaller discard

546 probability, and the number of fish at which the discarding probability is $50 \%$ is $26 \mathrm{~cm}$ ).

547 Apparently, from the fisher's perspective, the extra work of sorting a new marketable species is

548 only worth the effort for large catches, in terms of the size or number of fish caught. 


\section{CONCLUSIONS}

551 In summary, the strength of the interactions with benthos may be greater for the trammel

552 net fishery than for other small-scale métiers. Possible management measures for reducing

553 interactions may be developing new fishing technologies that reduce soaking time while, at the

554 same time, maintain revenues. However, any management measures should be adopted in

555 conjunction with the fishing sector. Despite the fact that most small-scale boats in Majorca

556 alternate different fishing strategies (or métiers) throughout the year, the lobster season represents

557 a substantial percentage of the annual revenues (Palmer et al., 2017). Therefore, new management

558 rules affecting the lobster trammel net fisheries may affect the whole small-scale fleet, because

559 most boats in Majorca may be at the limit of their economic viability. This statement is supported

560 by the negative trend in boat numbers experienced in recent decades (Grau et al., 2015). The fact

561 that landings remain constant while revenues are continuously decreasing suggests that the

562 dynamics of the fleet are not driven by the resource dynamics but by a marketing strategy that may

563 be improved (Palmer et al., 2017). Therefore, new management plans should only be enforced

564 after careful evaluation of both empirically demonstrated effects on long-term benthos dynamics

565 and on the economic viability of the small-scale fleet.

566

\section{ACKNOWLEDGMENTS}

568 This study is a result of the Associated Unit LIMIA-IMEDEA. The authors thank the fishermen 569 of Port d'Andratx, Portopetro and OPMallorcaMar for their collaboration in this study. 


\section{REFERENCES}

571 Amengual-Ramis JF, Vazquez-Archdale M, Canovas-Perez C, Morales-Nin B. 2016. The

572 artisanal fishery of the spiny lobster Palinurus elephas in Cabrera National Park, Spain:

573 Comparative study on traditional and modern traps with trammel nets. Fisheries Research 179:23-

57432 DOI: http://dx.doi.org/10.1016/j.fishres.2016.01.022

575

576 Aydin I, Gökçe G, Metin C. 2013. Using guarding net to reduce regularly discarded invertebrates

577 in trammel net fisheries operating on seagrass meadows (Posidonia oceanica) in Izmir Bay

578 (Eastern Aegean Sea). Mediterranean Marine Science 14:282-291. DOI:

579 http://dx.doi.org/10.12681/mms.425

580

581 Batista MI, Célia MT, Henrique NC. 2009. Catches of target species and bycatches of an

582 artisanal fishery: The case study of a trammel net fishery in the Portuguese coast. Fisheries

583 Research 100:167-177

584 DOI: https://doi.org/10.1016/j.fishres.2009.07.007

585

586 Benoit HP, Hurlbut T, Chasse J. 2010. Assessing the factors influencing discard mortality of

587 demersal fishes using a semi-quantitative indicator of survival potential. Fisheries Research

588 106:436-447. DOI: https://doi:10.1016/j.fishres.2010.09.018

589

590 Bilge G, Yapici S, Filiz H, Cerim H. 2014. Weight-length relations for 103 fish species from the

591 Southern Aegean Sea, Turkey. Acta ichthyologica et piscatoria 44: 263-269. DOI:

592 https://doi.org/10.3750/AIP2014.44.3.11 
594 BOE-A-2001-11324 ORDEN de 30 de mayo de 2001 por la que se regula la pesca de la langosta 595 "Palinurus spp." en las aguas exteriores próximas a las Illes Balears. 596 (https://www.boe.es/diario_boe/txt.php?id=BOE-A-2001-11324)

597

598 BOIB, Boletín oficial Núm. 038 - 29 / Marzo / 2001 Orden del Consejero de Agricultura y Pesca 599 de 23 de marzo de 2001, por la que se regula la pesca de la langosta (Palinurus spp.) en las aguas 600 interiores de las Illes Balears. (http://www.caib.es/eboibfront/es/2001/5761)

601

602 Borcard D, Gillet F, Legendre P. 2011. Numerical Ecology with R. Springer, New York, 302 603 pp.

604

605 Davis MW, Ottmar ML. 2006. Wounding and reflex impairment may be predictors for mortality 606 in discarded or escaped fish. Fisheries Research 82:1-6.

607 DOI:https://doi.org/10.1016/j.fishres.2006.09.004

608

609 Goñi R, Latrouite D. 2005. Review of the biology, ecology and fisheries of Palinurus spp. species 610 of European waters: Palinurus elephas (Fabricius, 1787) and Palinurus mauritanicus (Gruvel, 611 1911). Cahiers de Biologie Marine 46:127-142. Available at: 612 http://archimer.ifremer.fr/doc/00000/3625/

613

614 Gonçalves J M.S., Stergiou K I, Hernando J A, Puente E, Moutopoulos D K, Arregi L, 615 Soriguer MC, Vilasc C, Coelho R, Erzini K. 2007. Discards from experimental trammel nets in 
616 southern European small-scale fisheries. Fisheries Research. 88 5-14).

617 https://doi.org/10.1016/j.fishres.2007.06.017

618

619 Gökçe G, Bozaoğlu AS, Eryaşar R, Özbilgin H. 2016. Discard reduction of trammel nets in the

620 Northeastern Mediterranean prawn fishery. Journal of Applied Ichthyology 32:427-431. DOI:

621 https://doi.org/10.1111/jai.13015

622

623 Grau AM, Mayol J, Oliver J, Riera F, Riera I. 2015. Llibre Vermell dels Peixos de les Illes

624 Balears, Conselleria de Medi Ambient, Agricultura i Pesca, Spain.

625

626 Grieve C, Brady DC, Polet H. 2014. Best practices for managing, measuring and mitigating the 627 benthic impacts of fishing - Part 1. Marine Stewardship Council Science Series, 2:18-88.

628

629 Hall, S. J., and Mainprize, B. M. 2005. Managing by-catch and discards: how much progress are 630 we making and how can we do better? Fish and Fisheries, 6: 134-155.

631

632 Hinz H. 2016. The impact of bottom fishing on 'animal forests': Science, Conservation and 633 Fisheries Management. In: Marine Animal Forests: The Ecology of Benthic Biodiversity Hotspots, 634 Springer International Publishing. 19 pp.

635

636 Iglesias M, Massutí E, Reñones O, Morales-Nin, B. 1994. Three small-scale lisheries based on 637 the island of Majorca (NW Mediterranean). Monografies Bolletì de Societat d'Història Natural de 638 les Balears, 37: 35-58. ISSN 012-260X. 
640 Ilkyaz AT, Metin G, Soykan O, Kinacigil HT. 2008. Length-weight relationship of 62 fish 641 species from the Central Aegean Sea, Turkey. Journal of Applied Ichthyology 24:699-702. DOI: 642 https://doi.org/10.1111/j.1439-0426.2008.01167.x

643

644 Irvine LM, Chamberlain YM. 1994. Seaweeds of the British Isles, Vol 1. In: Rhodophyta, part 645 2B Corallinales, Hildenbrandiales, Ed. British Museum, Londres, 275p.

646

647 Kelleher, K. 2005. Discards in the world's marine fisheries. An update. FAO Fisheries Technical 648 Paper. No. 470. Rome, FAO. pp. 1-131

649

Maynou F, Morales-Nin B, Cabanellas-Reboredo M, Palmer M, Garcia E, Grau AM. 2013.

651 Small-scale fishery in the Balearic Islands (W Mediterranean): A socio-economic approach. 652 Fisheries Research 139:11-17. DOI: https://doi.org/10.1016/j.fishres.2012.11.006

653

654

Merino G, Morales-Nin B, Maynou F, Grau AM. 2008. Assessment and bioeconomic analysis 655 of the Majorca (NW Mediterranean) trammel net fishery. Aquatic Living Resources 21:99-107. 656 DOI: https://doi.org/10.1051/alr:2008027

657

658 Metin C, Gökçe G, Aydin İ, Bayramiç İ. 2009. Bycatch reduction in trammel net fishery for 659 prawn (Melicertus kerathurus) by using guarding net in İzmir Bay on Aegean Coast of Turkey. 660 Turkish Journal of Fisheries and Aquatic Sciences 9:133-136. DOI: 661 https://doi.org/10.4194/trjfas.2009.0202 
662

663 Morales-Nin B, Grau AM, Palmer M. 2010. Managing coastal zone fisheries: a Mediterranean 664 case study. Ocean \& Coastal Management 53:99-106. DOI: 665 https://doi.org/10.1016/j.ocecoaman.2010.01.003

666

667 Morey G, Moranta J, Massutì E, Grau AM, Linde M, Riera F, Morales-Nin B. 2003. Weight668 length relationships of littoral to lower slope fishes from the western Mediterranean. Fisheries 669 Research 62:89-96 DOI: https://doi.org/10.1016/S0165-7836(02)00250-3

670

Oksanen J, Blanchet FG, Kindt R, Legendre P, Minchin PR, O'Hara RB, Simpson GL, 672 Solymos P, Stevens MHH, Wagne H. 2015. Vegan: Community Ecology Package. R package vegan, vers. 2.2-1 Available at: http://cran.r-project.org/web/packages/vegan

Palmer M, Tolosa B, Grau AM, Gil MM, Obregón C, Morales-Nin B. 2017. Combining sale records of landings and fishermen knowledge for predicting métiers in a small-scale, multi-gear, multispecies fishery. Fisheries Research 195:59-70

DOI: https://doi.org/10.1016/j.fishres.2017.07.001

679

Plummer M. 2003. JAGS: A Program for Analysis of Bayesian Graphical Models Using Gibbs 681 Sampling. Proceedings of the 3rd International Workshop on Distributed Statistical Computing 682 (DSC 2003), March 20-22, Vienna, Austria. ISSN 1609-395X. Available at: 683 http://www.ci.tuwien.ac.at/Conferences/DSC-2003/ 684 
685 Plummer M, Best N, Cowles K, Vines K. 2006. Icoda: Convergence Diagnosis and Out-put 686 Analysis for MCMC." R News, 6:7-11 Available at: http://CRAN.R-project.org/doc/Rnews/. 687

688 Quetglas A, Gaamour A, Reñones O, Missaoui H, Zarrouk T, Elabed A, Goñi R. 2004. 689 Common spiny lobster (Palinurus elephas Fabricius 1787) fisheries in the western Mediterranean: 690 A comparison of Spanish and Tunisian fisheries. Bolleti de Societat d'Història Natural de les 691 Balears 47:63-80. ISSN 0212-260X.

692

Quetglas A, Merino G, Ordines F, Guijarro B, Garau A, Grau AM, Oliver P, Massutí E. 694 2016. Assessment and management of western Mediterranean small-scale fisheries. Ocean \& Coastal Management 133:95-104. DOI: http://dx.doi.org/10.1016/j.ocecoaman.2016.09.013

696

Regulation (EU) No 1380/2013 of the European Parliament and of the Council of 11 December 2013 on the Common Fisheries Policy (https://publications.europa.eu/en/publication-detail/-/publication/65394081-0736-49c1b819-0f9269e8ae15/language-en)

701

Stergiou KI, Moutopoulos DK, Erzini K. 2002 Gill net and longlines fisheries in Cyclades 703 waters (Aegean Sea): species composition and gear competition, Fisheries Research, 57: 25-37, https://doi.org/10.1016/S0165-7836(01)00334-4

705

706 Secci E, Cuccu D, Follesa MC, Cau A. 1999. Fishery and tagging of Palinurus elephas in 707 sardinian seas. In: Crustaceans and the biodiversity crisis. Ed by F.R. Schram Fr and J.C. von 
708 Vaupel Klein. Proceedings of the Fourth International Crustacean Congress, Amsterdam, The

709 Netherlands. Leiden, Brill. pp. 665-672.

710

711 R Core Team. 2008. R: A language and environment for statistical computing. R Foundation for

712 Statistical Computing, Vienna, Austria. Available at: https://www.R-project.org/.

713

714 Stergiou KI, Moutopoulos DK, Soriguer MC, Puente E, Lino PG, Zabala C, Monteiro P,

715 Errazkin LA, Erzini K. 2006. Trammel net catch species composition, catch rates and métiers in

716 southern European waters: A multivariate approach. Fisheries Research 79:170-182. DOI:

$717 \quad 10.1016 /$ j.fishres.2006.03.003

718

719 Therneau TM, Grambsch PM. 2000. Modeling Survival Data: Extending the Cox Model.

720 Springer, New York. 558 pp.

721

722 Tsagarakis K, Palialexis A, Vassilopoulou V. 2014 Mediterranean fishery discards: review of

723 the existing knowledge. ICES Journal of Marine Science 71:1219-1234.

724 DOI:10.1093/icesjms/fst074

725

726 Veiga P, Pita C, Rangel M, Gonçalves JMS, Campos A, Fernandes PG, Sala A, Virgili M,

727 Lucchetti A, Brčić J, Villasante S, Ballastero M, Chapela R, Santiago J, Agnarsson S,

728 Ögmundarson Ó, Erzini K. 2016. The EU landing obligation and European small-scale fisheries:

729 What are the odds for success? Marine Policy 64:64-71 DOI:

730 https://doi.org/10.1016/j.marpol.2015.11.008 
731

732 Wilson S, Blake C, Berges JA, Maggs CA. 2004. Environmental tolerances of free-living 733 coralline algae (maerl): implications for European marine conservation. Biological Conservation 734 120: 279-289. DOI: https://doi.org/10.1016/j.biocon.2004.03.001 


\section{Table $\mathbf{1}$ (on next page)}

The number of animals discarded that were alive at on-board arrival.

Only species with more than 30 observations are detailed. The immediate survival probability and $95 \%$ Bayesian credibility intervals are indicated. 


\begin{tabular}{|c|c|c|c|c|c|}
\hline \multirow[t]{2}{*}{ Species } & \multicolumn{2}{|c|}{$\begin{array}{c}\text { Number of } \\
\text { observed } \\
\text { animals }\end{array}$} & \multirow[t]{2}{*}{$\begin{array}{c}\text { Immediate } \\
\text { survival } \\
\text { probability }\end{array}$} & \multicolumn{2}{|c|}{$\begin{array}{c}\text { Bayesian } \\
95 \% \text { credibility } \\
\text { interval }\end{array}$} \\
\hline & Alive & Total & & $2.5 \%$ & $97.5 \%$ \\
\hline Palinurus elephas & 82 & 127 & 0.64 & 0.56 & 0.72 \\
\hline Parastichopus regalis & 30 & 33 & 0.92 & 0.80 & 0.98 \\
\hline Leucoraja naevus & 193 & 296 & 0.65 & 0.60 & 0.71 \\
\hline Raja sp. & 5 & 229 & 0.02 & 0.01 & 0.04 \\
\hline Raja clavata & 26 & 224 & 0.11 & 0.08 & 0.16 \\
\hline Scyliorhinus canicula & 12 & 161 & 0.07 & 0.04 & 0.12 \\
\hline Scorpaena scrofa & 4 & 100 & 0.04 & 0.01 & 0.08 \\
\hline Lophius piscatorius & 1 & 46 & 0.02 & 0.00 & 0.08 \\
\hline
\end{tabular}


Figure 1

Details of the strip added at the bottom of trammel nets (greca)

Greca net approximately $20 \mathrm{~cm}$ of nylon material with a mesh size of $45 \mathrm{~mm}$ that is sown to the bottom of the main net along its entire length.

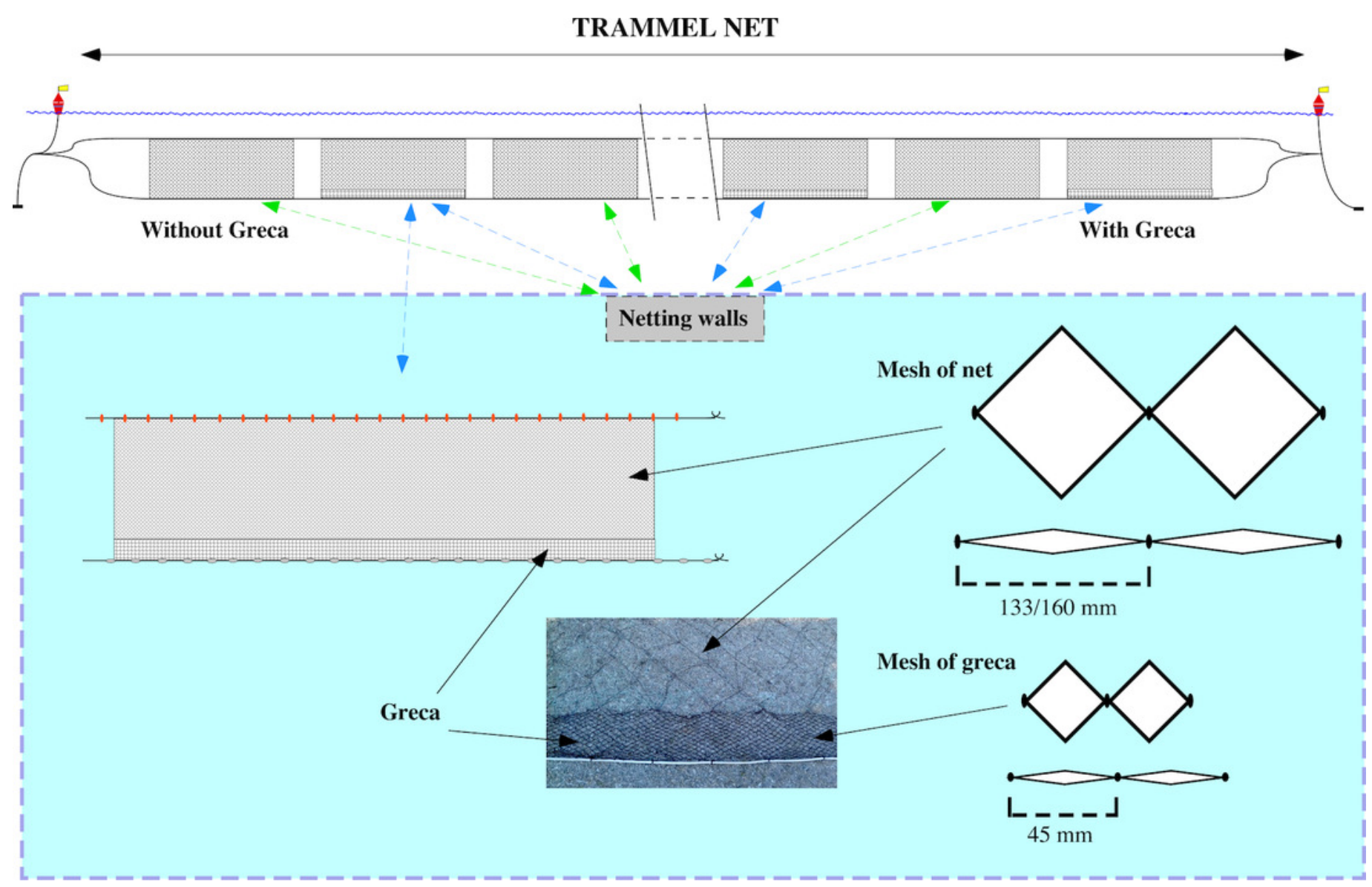




\section{Figure 2}

Principal components analysis (PCA) plot of all the small-scale boats from Majorca that targeted spiny lobster during the 2015 and 2016 spiny lobster seasons.

Between-boat similarity was estimated from the landed catches $(\mathrm{kg}$ of each one of 170 commercial categories) for all the daily fishing trips of the lobster trammel net fleet from Majorca. The grey points denote the average scores for all the boats (i.e., the centroid of all the fishing trips of a given boat). The larger, coloured points denote the three sampled boats. For them, an envelope polygon including all the fishing trips of each boat was added. Note that within-boat variability is similar to or even larger than between-boat variability. The number on the axis label indicates the proportion of variance explained by each of the first two PCA axes considered. 


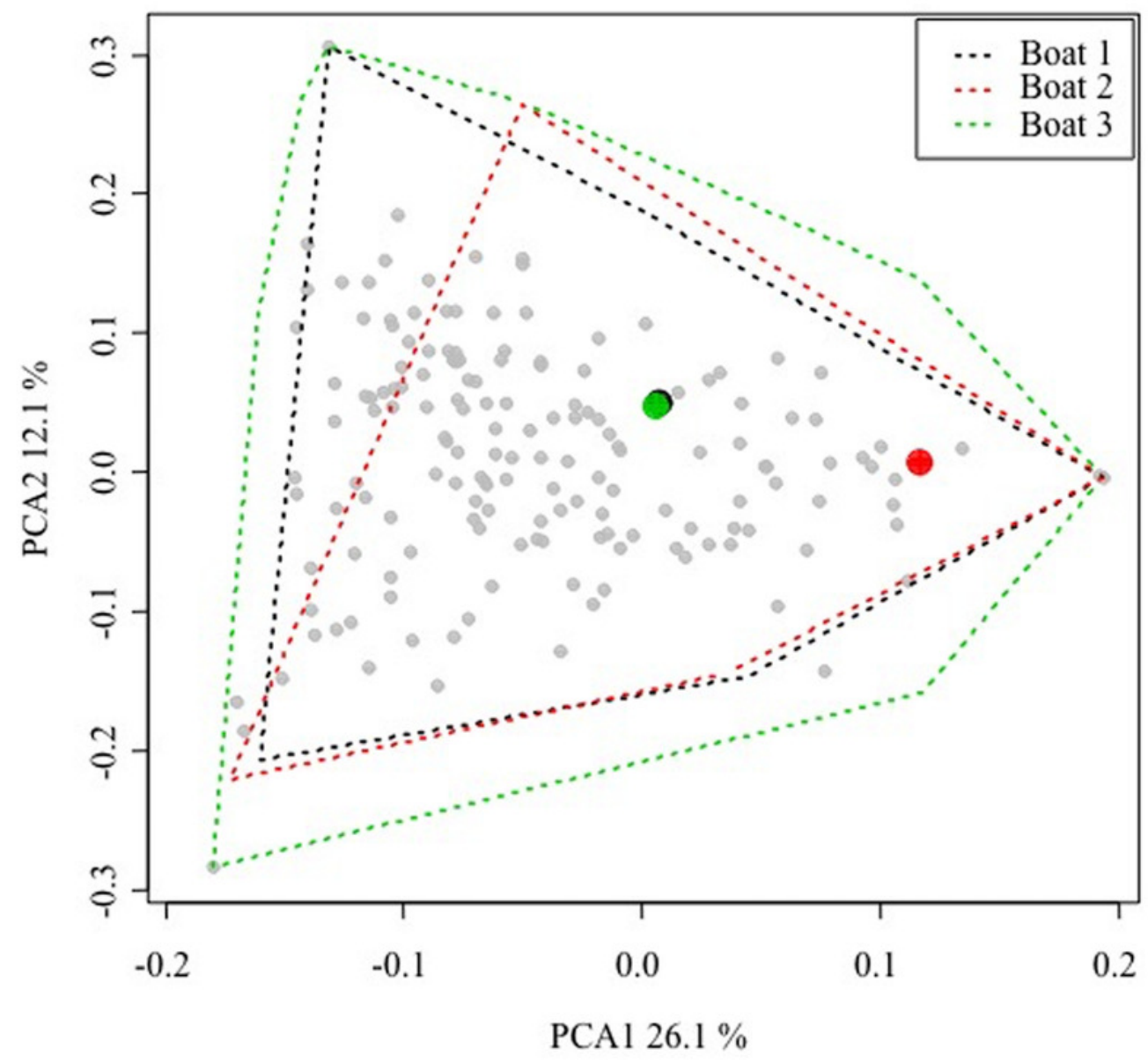




\section{Figure 3}

\section{Marketable catches and Discards}

A) Number of items per netting wall of Marketable catches (blue bars); and Discards nonmarketable species (red bars); B) Kg per netting wall of discards (non-marketable species), pooled for catch attributable at the netting wall/panel and whole net levels

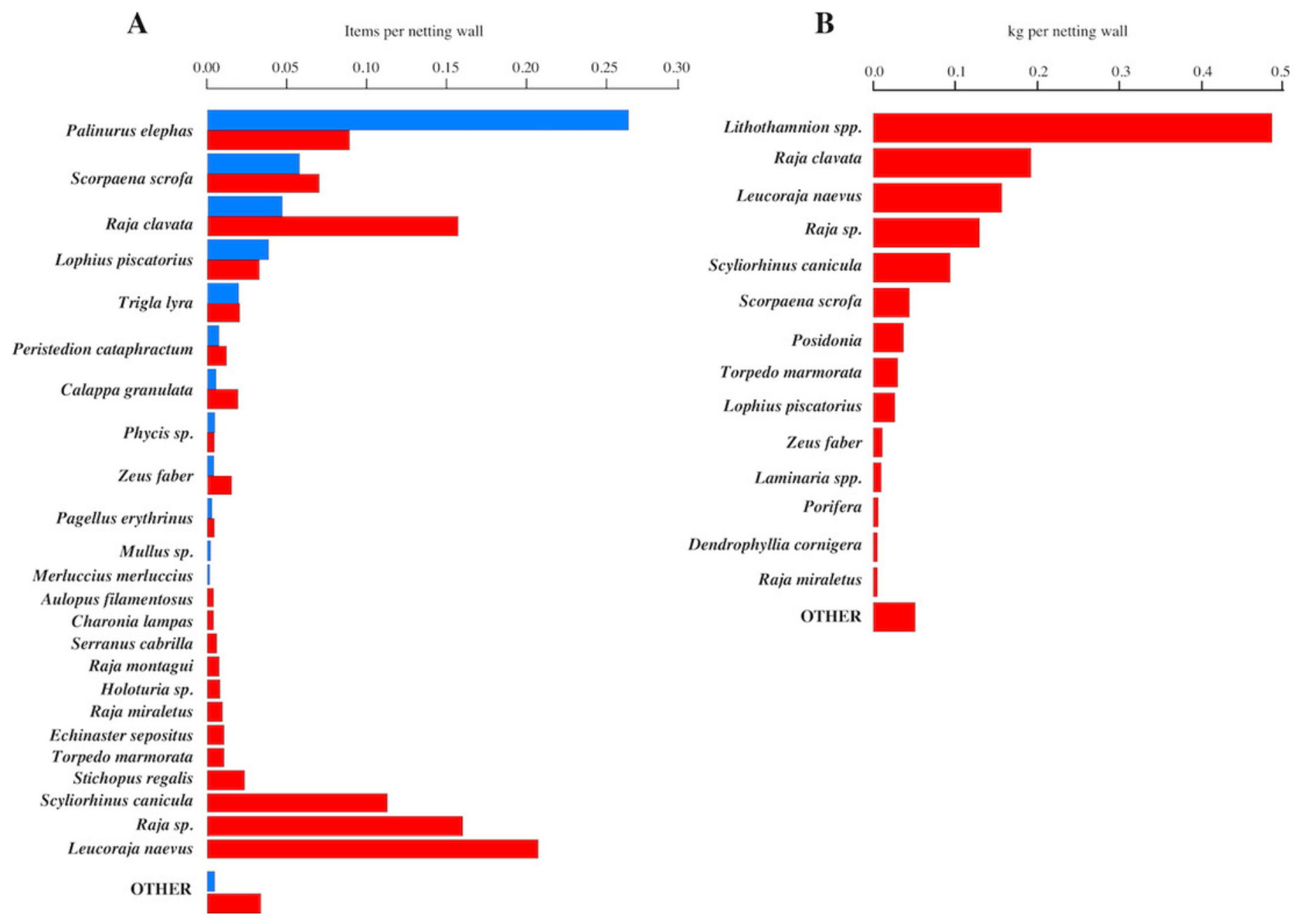




\section{Figure 4}

PMF versus MMF (panels $A$ and $C$ ) and MMF versus MMF + greca (panels B and D) comparisons

Comparing PMF versus MMF (panels $A$ and $C$ ) and MMF versus MMF + greca (panels $B$ and $D$ ) by (i) the ratio of netting walls with some catch (left panels); (ii) the revenue (in Euros) of the commercialized catches (panels A and B) or the weight of the discards ( $C$ and $D$ ) per netting wall with some catch (middle panels); and (iii) the revenue (in Euros) of the commercialized catches (panels $A$ and $B$ ) or the weight of the discards (panels $C$ and $D$ ) for an average (22 netting walls) net (right panels). Only items attributable to a given netting wall were used in these comparisons. 
A

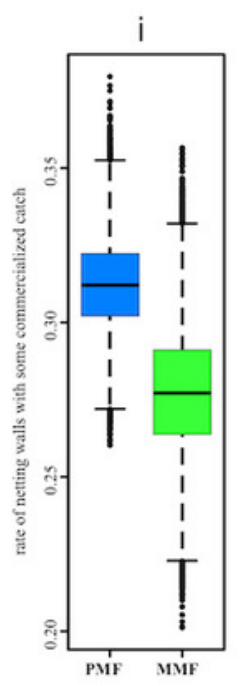

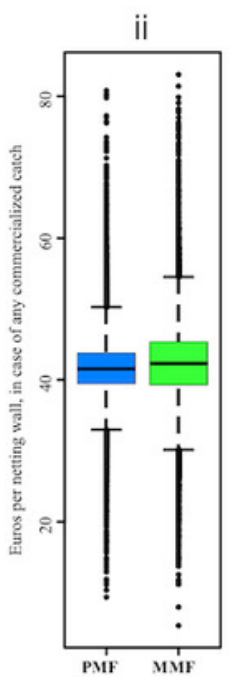

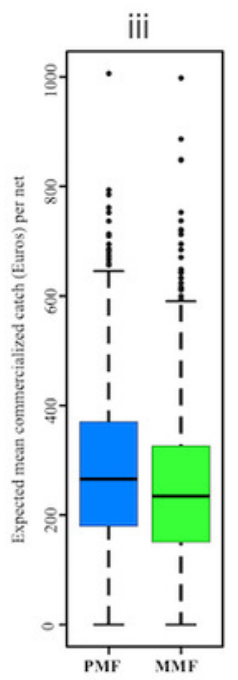

B
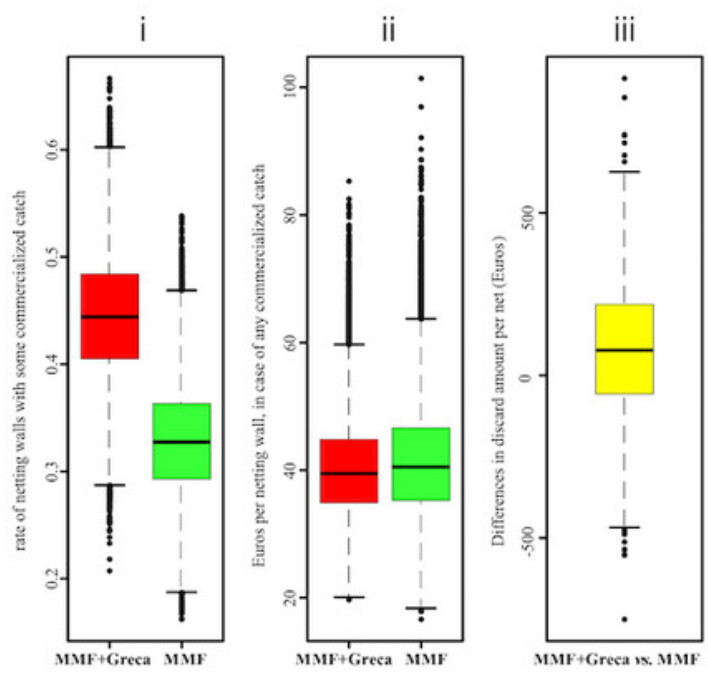

C

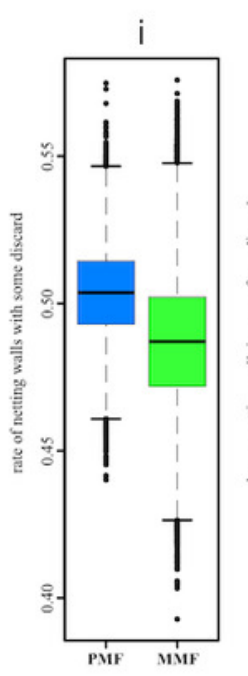

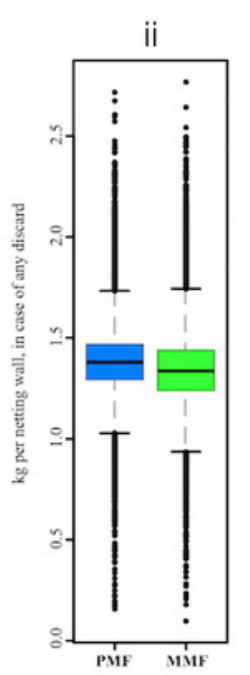

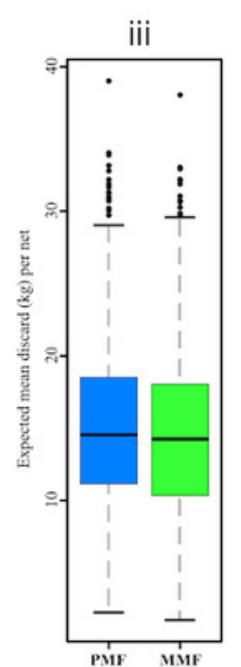

D

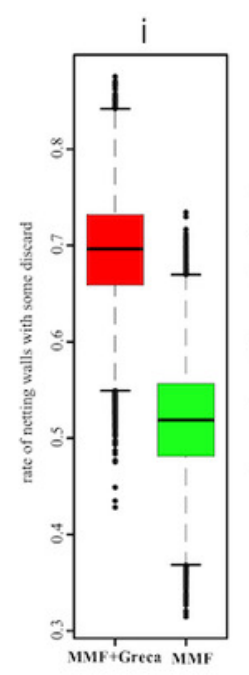

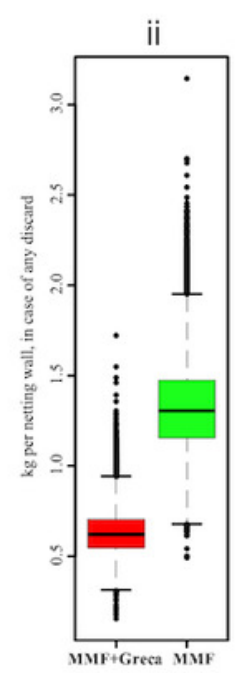

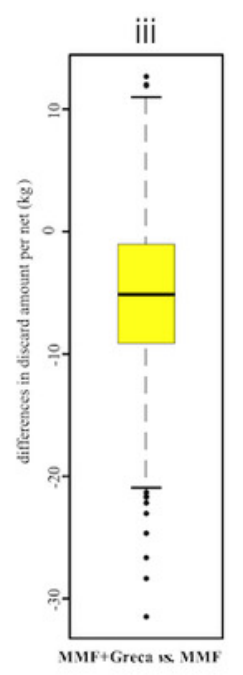


Figure 5

PCA of the discarded items attributable to a given netting wall (points in the figure)

The PMF and MMF largely overlap, but MMF + greca significantly differs in species-specific abundance. This difference is mainly related to a higher abundance of $S$. canicula.

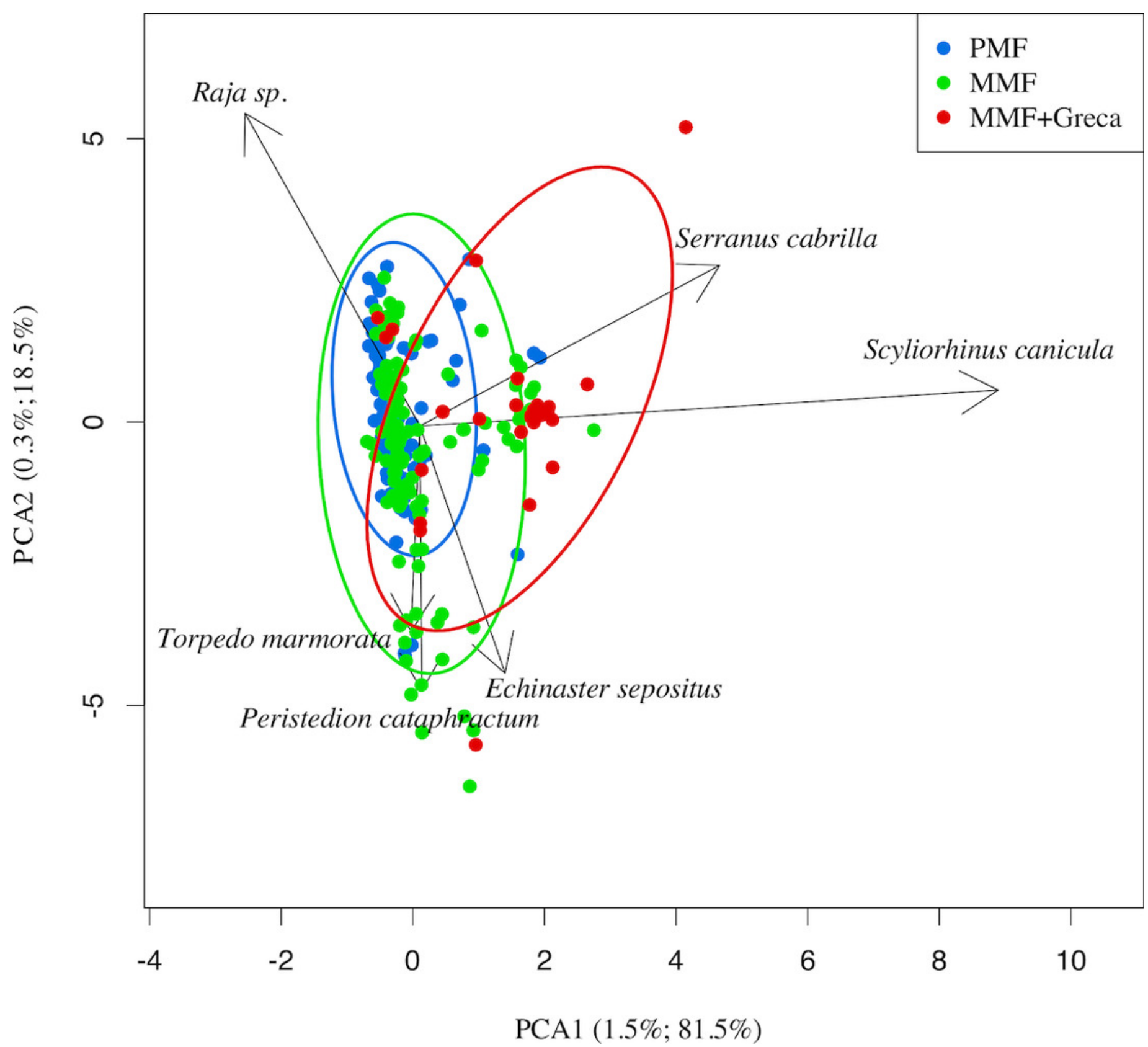


Figure 6

Abundance distribution ( $\mathrm{kg}$ per netting wall) of the species that contributed most to the differences in the discarded fraction between the different types of manufactured netting walls

A) Scyliorhinus canicula; B) Raja species
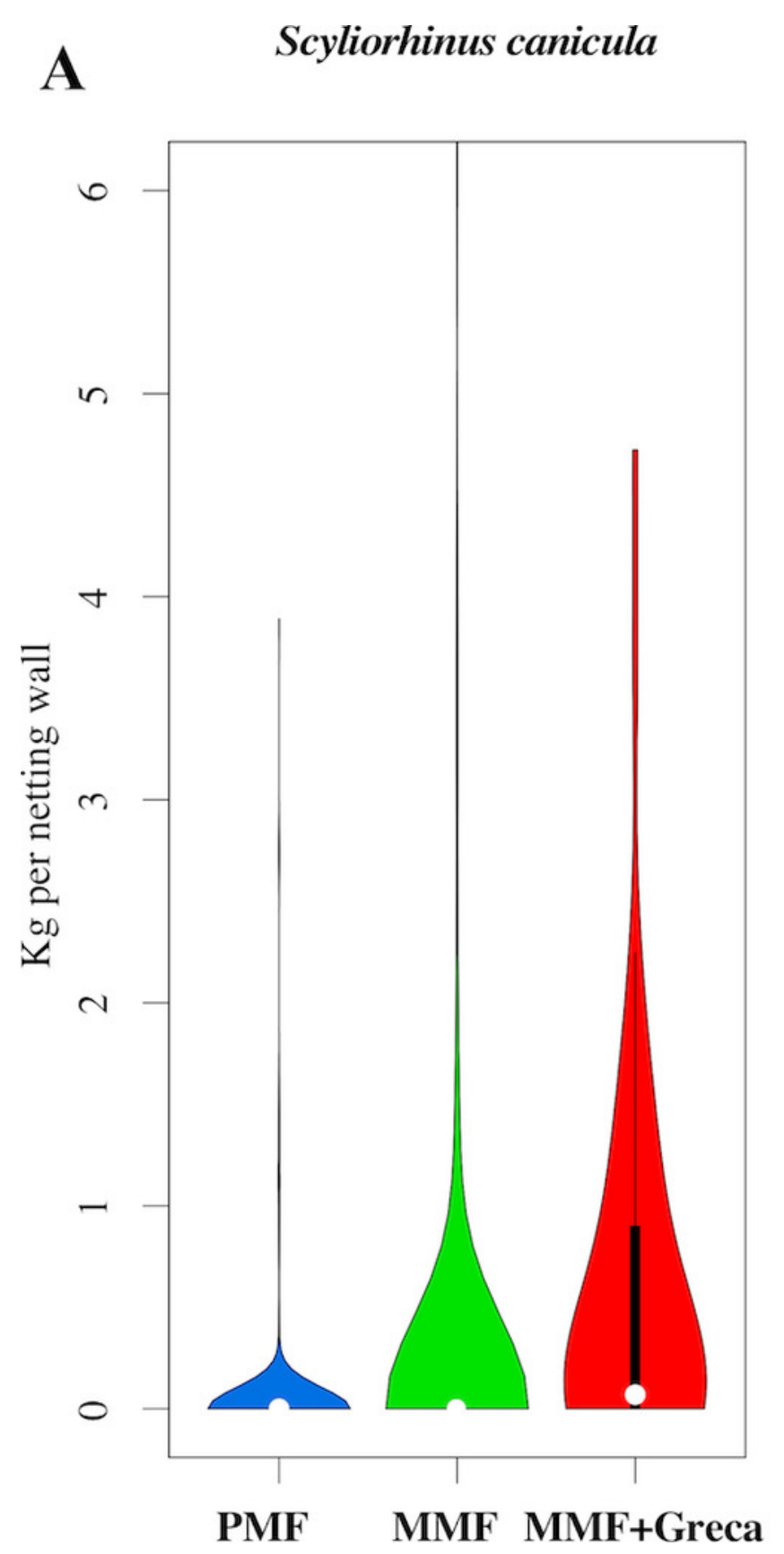

B

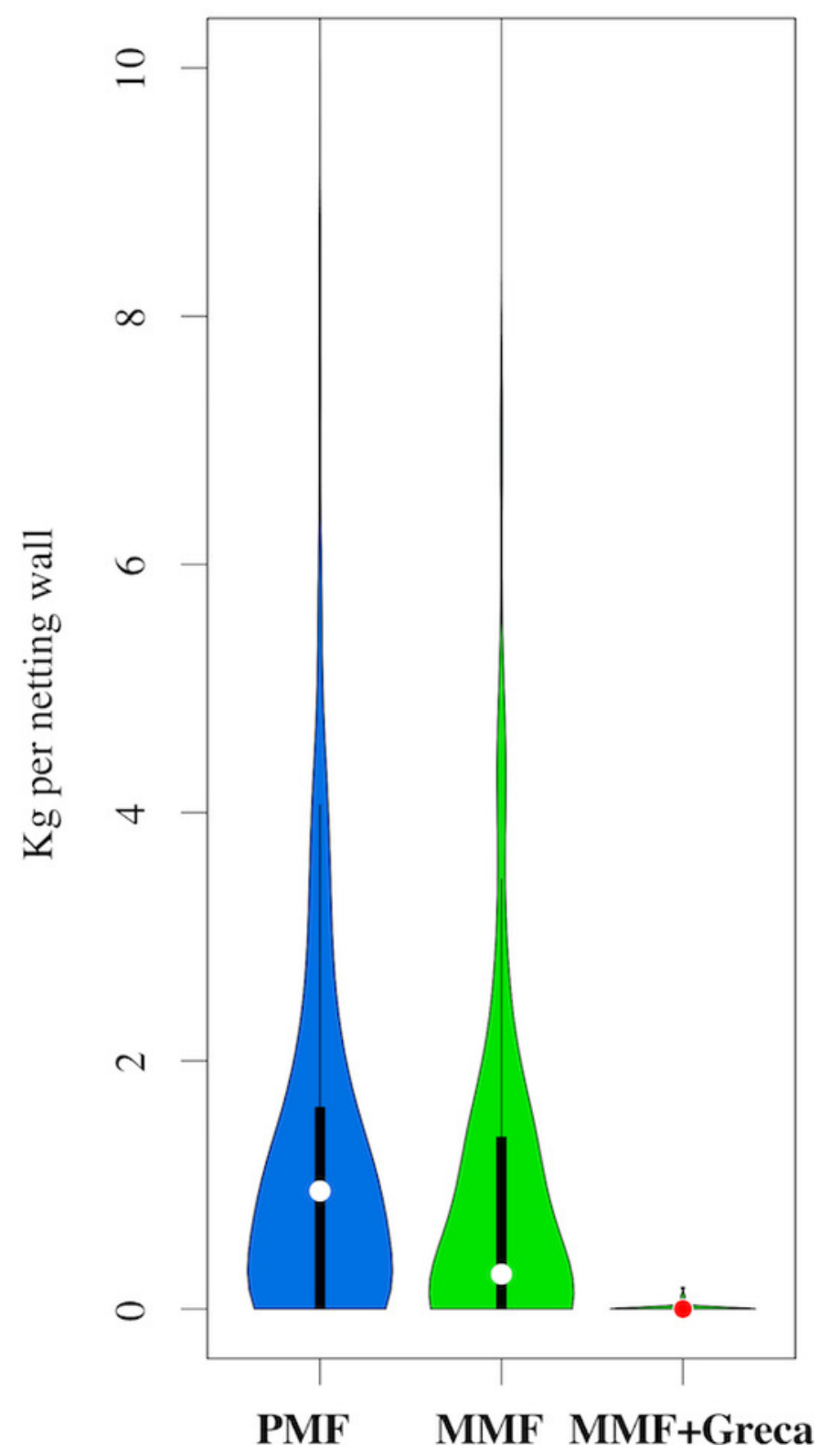


Figure 7

The proportion of discarded animals that were alive when they arrived on board

The Bayesian 95\% credibility intervals are indicated

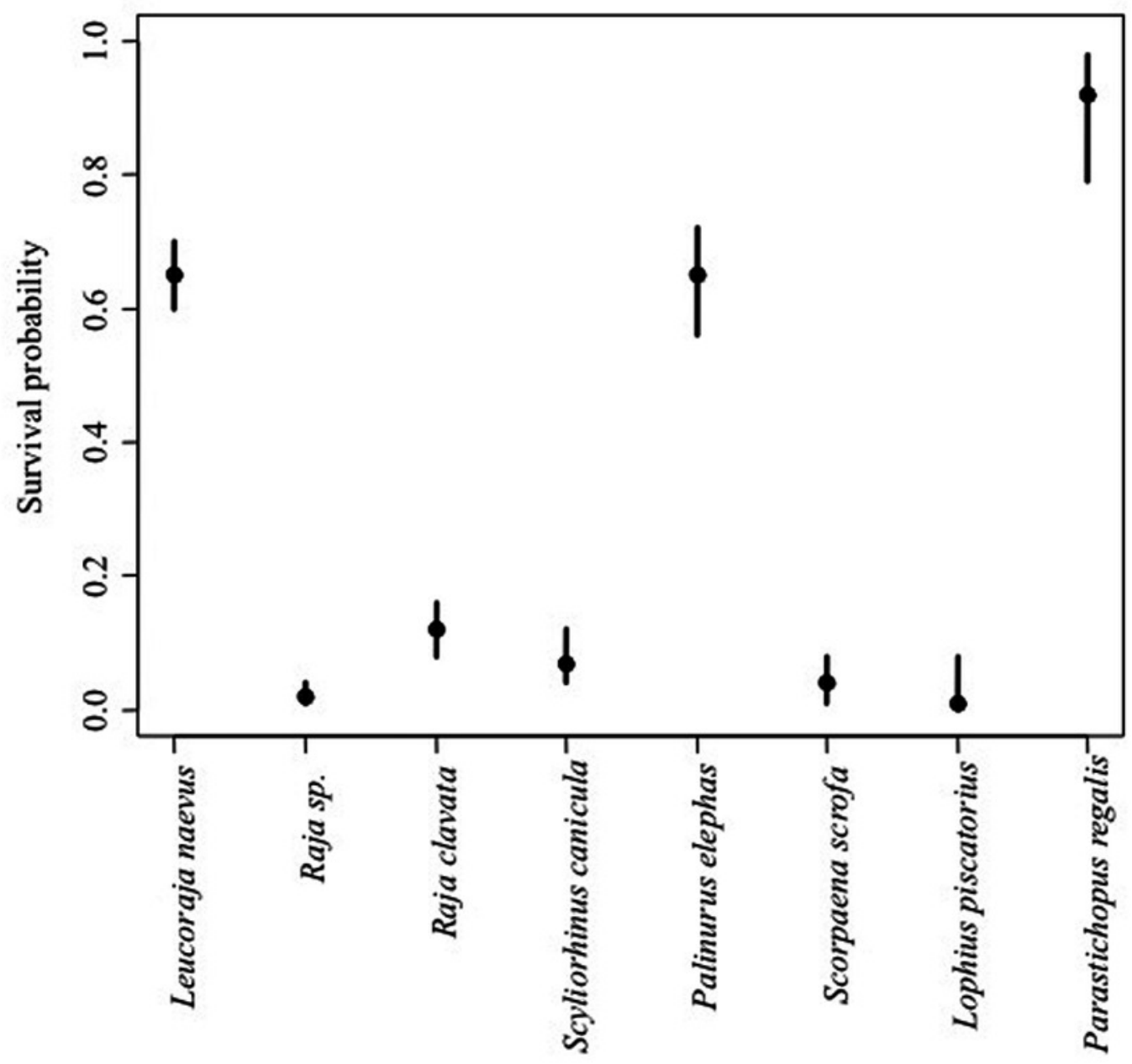


Figure 8

Changes in vitality status over time for the spiny lobsters caught and held in captivity for up to 7 days

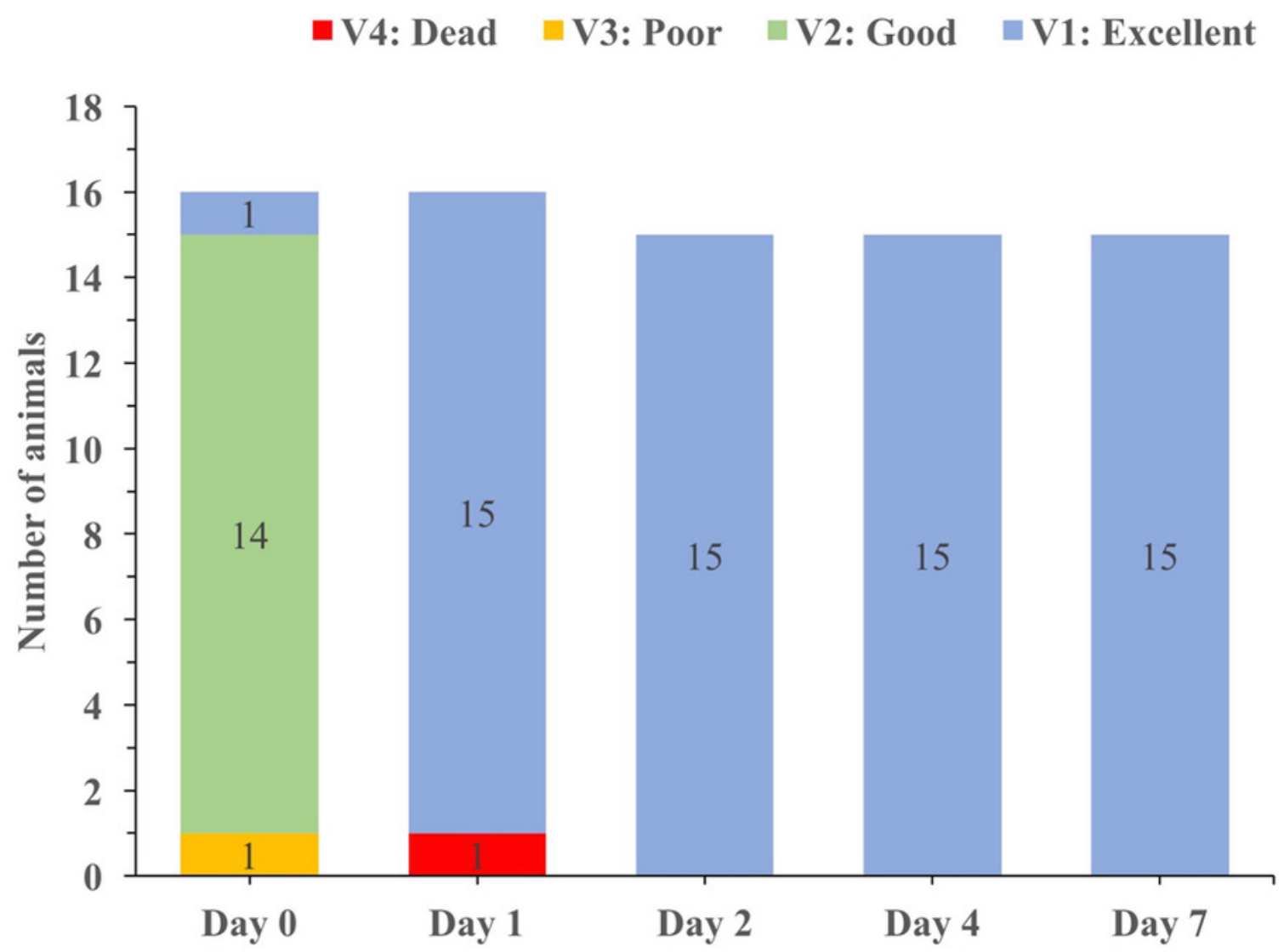

